\title{
Escape room as an adult education tool
}

\section{Michat Mijal, Martyna Cieśla, Monika Gromadzka}

University of Warsaw

mijal@wz.uw.edu.pl | ORCID: 0000-0003-0565-3337

mciesla@wz.uw.edu.pl | ORCID: 0000-0002-9254-8967

monika.gromadzka@uw.edu.pl | ORCID: 0000-0001-6628-0357

\begin{abstract}
Games gain popularity as teaching tools. Escape rooms, however, are a novelty, with most authors focusing on their description rather than the analysis of effects of their utilisation. The objective of this paper is to analyse experiences of players partaking in an educational escape game, and to observe escape rooms from the viewpoint of a scholar interested in the efficiency of the tool. The research material consists of questionnaires filled in by research subjects and transcripts of structured interviews. Due to the relatively large sample $(\mathrm{N}=258)$, it is possible to conclude from the gathered quantitative data that there has been a growth in the subjects' knowledge.
\end{abstract}

Keywords: escape room, adult education, serious games, structured interviews 



\section{Games and their potential}

The educational potential of games was discovered already in antiquity, with the first records regarding the use games in adult education in the modern era dating back to the $17^{\text {th }}$ century. Over time these games have evolved: from strategic war games designed for army officers up to training games used by educators during trainings and courses.

Games found their way to the mainstream of didactic and training tools only in the $20^{\text {th }}$ century. Since the 1940 , when Reginald Revans (1980) developed formal assumptions and laid the foundations for the so-called action learning, games paved their way as full-fledged education tools through games and simulations used in business schools and in professional development of large organisations employees, up to current numerous examples of traditional and electronic games used in schools and universities. It is difficult to unequivocally determine a moment in time when games were accepted by practitioners; but with their dissemination ever more terms describing games used in nonentertainment contexts surfaced: serious games (Kleitmann, Narciss, 2019), edutainment (Rattakom, Sanit, Ladawan, 2019), human-based computation games (Heselmans et al., 2013) or games with a purpose (AmiriChimeh et al., 2018). Games have found their place and stayed for good in training and recruitment (Raybourn, 2007), personal development (Kai et al., 2020), marketing (Arora, Saxena, 2015), or risk analysis (Wang, Neil, Fenton, 2020).

Apart from the business area of application, games are also used on various stages of school education. Depending on the country and its policies this use may be common (e.g. in Germany) or incidental (e.g. in Poland); yet a well-designed game will become popular despite language barriers and will be adapted to the local circumstances in each country. Among titles known in Poland there are such as Chłopska Szkoła Biznesu ('Rural Business School') and Oil City created by the Małopolska Institute of Culture, ZnajZnak ('SignSmart') or Kolejka ('Queue') developed by the Institute of National Remembrance, and numerous games designed by administration institutions, both central and local, e.g. Aktywuj Warszawę ('Activate Warsaw'), Rozegraj Miasto ('Play Out the City'), or Zagraj w Miasto ('Play the City'). 
The objectives of the abovementioned games are varied but they all share one dimension - in addition to giving entertainment they teach, educate, and help players gain new skills and knowledge. Chłopska Szkoła Biznesu disseminates information on the Małopolska region, provides an opportunity to train negotiation skills, and additionally teaches the basics of economics. Oil City teaches history, yet in terms of competences it emphasises entrepreneurial attitudes and behaviours. Rozegraj Miasto is a tool designed to promote the idea of public consultation.

\section{Educational and training games}

At present, there is no scientific consensus on a single binding definition of a training, or even educational, game. There are, however, some parts of the gameplay which separate a didactic game from a regular one: active interactions between players, players' capacity to make decisions, striving to obtain goals, and a context which limits players' actions. Another differentiating factor is the objective of the game, which triggers changes in players' attitudes. This goal should be unambiguous and external to the gameplay - participants should be able to apply the newly acquired knowledge and skills in real-life contexts (Łączyński, 2011). Currently, training games are most commonly used in adult education, which corresponds with a real demand on the development services market.

Alf Wang, Terje $\emptyset$ fsdahl, and Ole Mørch-Storstein systematised the taxonomy of educational games in terms of players' engagement, coherence of the fantasy game reality, and the purpose of the training, as well as the game concept type. They divided educational games into intrinsic, where challenges faced by the players are related to the narrative and the fantasy world, and extrinsic, whose content is not dependent upon the narrative of the game. The figure below depicts the taxonomy of educational games. 


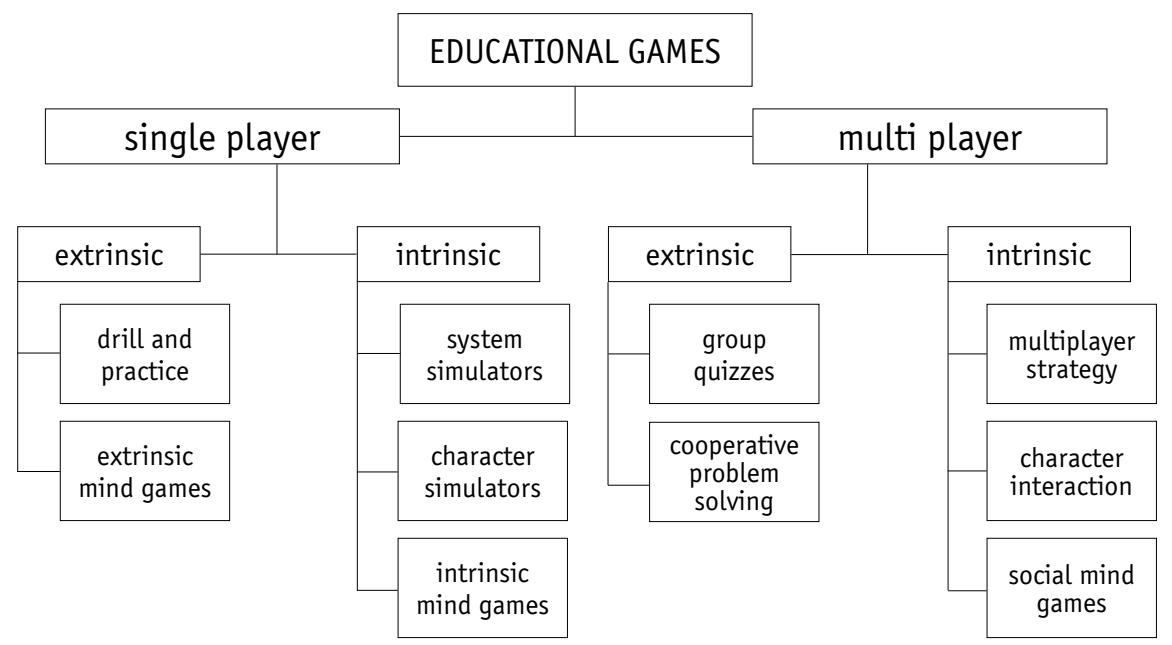

Figure 1. Taxonomy of educational games. Source: Wang, Øfsdahl, Mørch-Storstein, no date, p. 9

As presented above, there are ten main categories of educational games:

- drill and practice - here the player answers questions by choosing one from several text or graphic answers;

- extrinsic mind games - the player faces an intellectual challenge which is not related to the fantasy reality of the game;

- system simulators - here the player influences the course and the outcome of the gameplay, and the game fantasy world is a complex system subject to rules and principles;

- character simulators - the player becomes a hero of the narrative and their control over the gameplay is limited to the one character. They do not influence the story or the environment of the game;

- intrinsic mind games - this type of games challenges the players with intellectual puzzles closely related to the narrative in such a way that each decision a player makes results in instantaneous feedback;

- group quizzes - games of this type share common rules with games from the 'drill and practice' category; however, they demand that the players communicate within the gameplay and outside of it;

- cooperative problem solving - in mind games of this type the narrative does not affect given tasks and the players can influence other players; 
- multiplayer strategy - here both players' actions and the narrative affect the course of the gameplay;

- character interaction - games of this type are based on simulations of interactions between characters controlled by the players;

- social mind games - here the players face several intellectual challenges and they cooperate to solve them. They constantly receive feedback on their decisions and undertaken actions.

This taxonomy supports designing a game which will provide optimal learning conditions for adults in accordance with the subject and the objective of the course or training (Wang, Øfsdahl, Mørch-Storstein, no date).

Games as learning tools in adult education have numerous advantages. First of all, games provide a possibility of practical, empiric use of theoretical knowledge, which allows learners to make mistakes, self-reflect on the cause of their failure, and finally change and update their behaviour. Additionally, any threat to the safety of learners and their environment is minimalised through constant supervision and assistance of the facilitator (Anderson, Anderson, Taylor, 2009).

Secondly, learning through games is a multidimensional phenomenon. The players learn:

- simultaneous contextual usage of information which is a part of a dynamic narrative,

- limited processes between players,

- strategic analysis of risks, costs, outcomes, and rewards related to making decisions regarding solving of a given problem.

Thirdly, learners partaking in a didactic game can verify the effectiveness of their new mode of conduct and way of thinking, as well as use newly acquired skills and attitudes. The environment of a game is safe, hence they can avoid the negative consequences of a failure, which would be inevitable in reality (Raybourn, Waern, 2004).

Even this fragmented and superficial description proves that knowledge and skills taught through games vary. Depending on the mechanical solutions applied in the game and the project components, the range of application may be extremely wide. Escape rooms are an example of hybrid games with an unexplored educational potential currently popular all over the world. 


\section{Escape room as a learning experience}

Due to their specific hybrid nature, escape rooms are found on the border of multiplayer extrinsic and intrinsic games in the abovementioned taxonomy. They are played in teams (although single player escape rooms exist, an overwhelming majority of escape rooms is designed for several players) in dedicated places (or temporarily dedicated places in the case of mobile escape rooms), and the character of puzzles found inside is highly diverse - from regular number puzzles, through more complex word-based head-scratchers, up to multistage challenges demanding the integration of a wide range of skills and knowledge.

Escape rooms are relatively new creations. The first one was produced in 2007 in Kyoto. A rapid growth of the number of escape rooms was recorded around 2010 in Asia, subsequently in Europe, later in Australia, Canada, and the United States of America. The first Polish escape room was established by the Let Me Out company, emerging in Wrocław in 2013. Within the next three years about a thousand more surfaced (Stasiak, 2016).

Escape room is a team role-playing game whose narrative takes place in real time in a limited space of a room. The players' task is to uncover clues, solve puzzles, complete challenges, and find the key to the locked doors or a special item - an artifact. The game is usually designed for small teams, up to several members.

This form provides a social, entertainment, and educational experience which engages players, prompts them to collaborate, provokes creativity and logical thinking. Although every gameplay is similar, each one is unique as well as technically and story-wise inimitable. There is no one escape room which serves as the beginning of the phenomenon but there are many various sources.

Escape room creators seek narrative and puzzle inspiration in TV shows and various movie genres, be it adventure, action, horror, or science-fiction. They look for ideas in books, computer games, history, and themed entertainment industry. There is no denying that an escape room experience should resemble a fantastic adventure (Nicholson, 2015). 


\section{The 'Games of Food' project}

The main objective of our EIT Food 'Games of Food' project (consisting of six universities and other institutions ${ }^{1}$ and run in years $2018-2020$ as part of the Horizon 2020 network) is to create an education-communication tool which would facilitate the conveying of reliable, science-based data on nutrition and balanced diet. The 'Games of Food' project is a collaborative effort of experts in various fields: education, psychology, food and nutrition, environment and natural resources, game design, business. It consolidates institutions from Europe and Asia. Our goal is to raise knowledge and awareness of balanced nutrition and a healthy lifestyle through the design and application of escape games.

We chose the escape room as the first game format as we anticipated it could provoke deeper consideration and at least modest change in the eating habits of the participants of our research, measured afterwards via a questionnaire. Additionally, our research consortium used elements of popular culture to design the Zombie Attack escape game.

Since Zombie Attack is an escape game dedicated to adults and older teenagers, it was only natural to draw on the legacy of andragogy. It turned out, however, that although the escape room as a social and educational phenomenon is an extremely interesting form from the andragogical point of view, it has not yet become a basis for exploration research, apart from sparse analyses.

When creating the theoretical background and methodological guidelines, we drew from discussions on differences in children and adult learning (Appelt 2005; Brzezińska, Wiliński, 1995) and emotional and social factors in adult learning (Illeris, 2006; Jarvis, 2011; Bandura, 2007), and we assumed as the foundation Jack Mezirow's works on transformative learning. Hence, we presumed, in accordance with the concept of transformative learning, that the escape room would serve as the beginning of the reframing process - the experience provided should provoke a disorienting dilemma. It means that the dilemma can occur throughout "being in" an escape room and solving puzzles.

1 University of Helsinki, University of Warsaw, Israel Institute of Technology Technion, University of Reading, VTT, EUFIC. 
The experience of participating in an escape room may be more or less contradictory with one's previous beliefs about healthy eating, and therefore the disorienting dilemma can appear. It happens when people have the sense that their frame of reference may not be right for some reason. To sum up, we chose the escape room because it gives a chance to „be in" and act on a new perspective; it also provides an opportunity to relate to others going through the same experience, which can prove transformative to some of them.

The game spans several categories of Wang, $\varnothing$ fsdahl, and Mørch-Storstein's taxonomy but the crucial ones are extrinsic multiplayer experiences (group quizzes and cooperative problem solving).

\section{The Zombie Attack escape game}

The room itself consists of nine tasks, each dedicated to one area of knowledge on nutrition, balanced diet, and environmental factors of food production. The puzzles are organised in a logical order, where the aim is not only to smoothly introduce the players to the game, but also to progressively incorporate more complex food-related topics and ideas. The game starts with two simple logical tasks where players fill in gaps in the food pyramid using provided options and use a hidden code to decipher texts on the energy of essential nutrients. The poster depicting the food pyramid with missing pieces is glued to a white board. Around it players find small magnets, each corresponding to a specific food item, missing from the food pyramid. The code concealed in the food pyramid allows the players to determine which one of several scrolls hidden in the room is correct, and where another code is hidden. Then they encounter two mathematical tasks which teach them about food energy calculation and protein daily value. Participants are provided with correct formulas and they need to apply them adequately to provided numbers. The next puzzles require logical thinking and perceptivity - players need to read a booklet on essential amino acids and discover a message hidden in the text (i.e. colored letters), piece together a jigsaw puzzle depicting examples of complete protein food plants, and analyse a cookbook with healthy recipes in order to find a secret code, again hidden in the letters. 
The last puzzle is video-based - players watch a short film which contains information on the impact of food production on the environment (dressed as a last warning of several zombie apocalypse survivors) and look for word-based clues which help them discover the answer essential to escaping and winning the game.

\section{Research methodology}

Since the main goal of the eIT Food 'Games of Food' project was to design and test the application of science-based escape rooms as an educational tool, members of the EIT Food 'Games of Food' consortium developed an elaborate methodology of mixed methods research (survey, observation, and interview). We chose mixed methods research because it allows researchers to explore diverse perspectives and relationships that exist between the complex layers of multifaceted research questions. We realized that this methodological approach still had many critics and was very challenging, but it also enabled us to obtain data that indicated further possible research directions.

Quantitative data were collected through questionnaires filled by participants before and after the game. Interviews were conducted four weeks after the game.

Pre- and post- questionnaires helped evaluate the effectiveness of the Zombie Attack escape room. They were designed in regard to the local specificity of member countries, as well as to the tradition- and historyrelated differences in the understanding of healthy nutrition. There were multiple objectives of the questionnaire:

- to learn if the escape room can actually be an efficient teaching tool providing knowledge beneficial for the users;

- to learn if knowledge acquisition in the escape room is long-term;

- to verify the planned key performance indicators ${ }^{2}$;

- to test, evaluate, and improve the game;

- to create a methodological base for further escape games on similar topic.

2 Number of players in total, number of online media impressions, etc. 
On the one hand, since there were numerous diverse objectives, the questionnaire had to consist of several modules - each devoted to another element of the game. On the other hand, time limitations related to filling out the questionnaires before and after the game forced us to introduce some simplifications. That is why much of the information contained in the conclusion section may be analysed more thoroughly in other versions of the escape room prepared in future, when the object of the research is defined more narrowly.

The questionnaire consisted of the following modules:

- metrics;

- knowledge on nutrition;

- association test;

- eating habits and healthy eating;

- readiness to learn about healthy nutrition;

- escape room experience.

The last stage of the research was structured interviews conducted with randomly selected subjects approximately two weeks after the escape game. The interviews constituted a supplementary source and regarded i.a. changes in attitude and behaviour observed by the subjects after the Zombie Attack escape room experience.

The tests were conducted in five countries: Belgium, England, Finland, Israel, and Poland, with 258 participants over the course of three months between September and November 2018. The subjects' ages ranged from 18 to 61 , the majority being women, university students, and university staff. The teams consisted of two to eight players. They all completed the abovementioned pre- and post-test questionnaires.

\section{Research results}

Since the entertainment aspect of the Zombie Attack escape game was equally important as the educational aspect, both areas were analysed in the questionnaire. All subjects, without exceptions, rated the game experience as highly pleasurable. On the one hand, this may constitute a promising result which suggests that utilising an escape room in adult education could diversify and improve the attractiveness of the didactic 
process. On the other hand, a risk exists that sample selection led to inviting mostly the persons who enjoyed this kind of entertainment (the subjects were mostly students and employees of the University of Warsaw from the Pedagogy and Management Faculties, or from other academic centres in the case of other countries). The second, educational area provided more interesting and promising results.

The research included pre- and post-questionnaires concerning knowledge on healthy nutrition and motivation to learn about it. They consisted of 49 and 36 questions, respectively, mostly regarding eating habits, free associations with the topic, and the subjects' opinion on the matter of nutrition as well as on escape rooms applied in education. Eight questions tested the respondents' specific knowledge on nutrition; the table below presents the participants' answers.

Table 1. Percentage of responders who chose correct answers

\begin{tabular}{|c|c|c|c|}
\hline Question & PRE & POST & CHANGE \\
\hline How many calories are there in $1 \mathrm{gram}$ of protein? & $37 \%$ & $72 \%$ & $35 \mathrm{pp}$ \\
\hline $\begin{array}{l}\text { What nutrients form the basis of energy calculation } \\
\text { of food products? }\end{array}$ & $81 \%$ & $91 \%$ & $10 \mathrm{pp}$ \\
\hline $\begin{array}{l}\text { How many grams of protein are recommended for } \\
\text { a person to consume per day? }\end{array}$ & $29 \%$ & $45 \%$ & $16 \mathrm{pp}$ \\
\hline What are essential amino acids? & $56 \%$ & $71 \%$ & $15 \mathrm{pp}$ \\
\hline What are complete proteins? & $62 \%$ & $71 \%$ & $9 \mathrm{pp}$ \\
\hline What are complementary proteins? & $33 \%$ & $51 \%$ & $18 \mathrm{pp}$ \\
\hline How much of the human body is protein? & $36 \%$ & $39 \%$ & $3 \mathrm{pp}$ \\
\hline What are the functionalities of proteins in our body? & $55 \%$ & $64 \%$ & $9 \mathrm{pp}$ \\
\hline
\end{tabular}

In line with the expectations, quantitative results unequivocally show that the subjects gained knowledge on healthy nutrition during the game. In all knowledge-checking questions, without exceptions, the players achieved on average a third more points for correct answers in post-questionnaires than in pre-questionnaires. Based on this, it can be assumed that learning materials and puzzles applied in the escape room contained information presented in an accessible and understandable 
way. Understanding the differences in the increase of correct answers among participants requires thorough and more representative analyses; yet obtained results give reason to believe that escape rooms as adult education tool constitute an alternative to other teaching methods.

Additionally, 34 structured interviews were conducted with randomly chosen participants of the quantitative part of the study. During the interviews 9 general questions on awareness and habits were asked. As far as quantitative data derived from questionnaires suggest a change in the subjects' knowledge, qualitative data (players' testimonies obtained during interviews) imply that the Zombie Attack escape room experience may have had a long-term impact in terms of attitudes and behaviours. Most responders said that the knowledge gained during the game affected their habits in the area of healthy eating, as well as their attitude towards animal- and plant-based protein, e.g.:

respondent 66884: After the game I genuinely started to think that it is actually true that the proteins we mainly get from meat and animal products, they can be sourced from plant products. And you can really try to prepare meals with plant products. I, for one, when I cook, started to replace meat with red beans. I really like it. It tastes good and I know it is a great source of protein.

\section{Summary}

Whereas the results concerning the entertainment aspect of the escape room experience are not surprising, the educational aspect - the main dimension from the point of view of andragogy practitioners - instills careful optimism regarding the use of escape rooms in adult education. At the same time, certain methodological reservations limiting the scope of the conclusions cannot be omitted.

The changes in subjects' attitudes were perceived by the subjects themselves, thus the results are burdened with the self-description accuracy mistake. The sample of those who took part in experiments and were interviewed was not representative, which limits the possibility to generalise conclusions to a wider population. However, the statements concerning attitude and behaviour change constitute a useful starting point for further experiments, this time using elaborate sample selection tools. 
This is also an argument in favour of devoting more attention to escape rooms as tools applied in adult education. Even if subsequent experiments provide dissimilar results, one cannot dismiss the fact that among adult education tools escape rooms are likely to constitute an eligible alternative to many other methods used hitherto.

\section{References}

Amiri-Chimeh, S., Haghighi, H., Vahidi-Asl, M., Setayesh-Ghajar, K., Gholami-Ghavamabad, F. (2018). Rings: A Game with a Purpose for Test Data Generation. Interacting with Computers, 30(1), 1-30.

Anderson, B., Anderson, M., Taylor, T. (2009). New Territories in Adult Education: Game-based Learning for Adult Learners. Online: <www. newprairiepress.org/cgi/viewcontent.cgi?article=3747\&context=aerc $>$. Access date: 12 November 2019.

Appelt, K. (2005). Środkowy okres dorosłości. Jak rozpoznać potencjał dojrzałych dorosłych? W: A. I. Brzezińska (red.), Psychologiczne portrety człowieka. Praktyczna psychologia rozwojowa (s. 503-552), Gdańsk: Gdańskie Wydawnictwo Psychologiczne.

Arora, A., Saxena, A. (2015). "Supply Chain-Marketing Shark Tank" Experiential Lab Game in Interdisciplinary Business Education: Qualitative and Quantitative Analyses. Decision Sciences Journal of Innovative Education, 13(1), 21-43.

Brzezińska, A., Wiliński, P. (1995). Wspomaganie rozwoju człowieka dorosłego. Edukacja Dorosłych, 3, 17-33.

Bandura, A. (2007). Teoria społecznego uczenia się (tłum. J. Kowalczewska, J. Radzicki). Warszawa: Wydawnictwo Naukowe PwN.

Heselmans, A., Aertgeerts, B., Donceel, P., Van de Velde, S., Vanbrabant, P., Ramaekers, D. (2013). Human Computation as a New Method for Evidence-Based Knowledge Transfer in Web-Based Guideline Development Groups: Proof of Concept Randomized Controlled Trial. Journal of Medical Internet Research, 15(1).

Illeris, K. (2006). Trzy wymiary uczenia się (tłum. A. Jurgiel), Wrocław: Wydawnictwo Naukowe Dolnośląskiej Szkoły Wyższej. 
Kai, K., Jinxuan, L., Lingyun, G., Jing, Z. (2020). How to Improve Customer Engagement: A Comparison of Playing Games on Personal Computers and on Mobile Phones. Journal of Theoretical \& Applied Electronic Commerce Research, 15(2), 76-92.

Kleitmann, S., Narciss, S. (2019). Applied Metacognition: Real-World Applications Beyond Learning. Metacognition and Learning, 14(3), 335-342.

Łączyński, M. (2011). Gry szkoleniowe w nauczaniu dorosłych. Metoda i zastosowanie na przykładzie gry komunikacyjno-decyzyjnej MaxCom. Homo Ludens, 1(3), 71-80.

Mezirow, J. (1991). Transformative Dimensions of Adult Learning, San Francisco: John Wiley \& Sons Inc.

Mezirow, J. (2000). Learning to Think Like an Adult: Core Concepts of Transformation Theory. W: J. Mezirow (red.), Learning as Transformation. Critical Perspectives on a Theory in Progress (s.3-33). San Francisco: Jossey-Bass.

Mezirow, J. (2009). An Overview on Transformative Learning. W: K. Illeris (red.), Contemporary Theories of Learning: Learning Theorists... In Their Own Words (s. 90-105), London - New York: Routledge Taylor \& Francis Group.

Nicholson, S. (2015). A Recipe for Meaningful Gamification. Online: $<$ http://scottnicholson.com/pubs/recipepreprint.pdf $>$. Access date: 12 November 2019.

Rattakom, L., Sanit, T., Ladawan, W. (2019). The Web-Based Collaborative Edutainment Learning Model for Enhancing English Language Competency. Journal of Education, 13(3), 195-207.

Raybourn, E, Waern, A. (2004). Social Learning Through Gaming. Online: <www.researchgate.net/publication/221516137_Social_learning_through_gaming $>$. Access date: 12 November 2019.

Raybourn, E. M. (2007). Applying Simulation Experience Design Methods to Creating Serious Game-Based Adaptive Training Systems. Interacting with Computers, 19(2), 206-214.

Revans, R. (1980). Action Learning: New Techniques for Management. London: Blond \& Briggs, Ltd.

Stasiak, A. (2016). Escape rooms - nowa oferta sektora rekreacji w Polsce. Turyzm, 26, 33-49. 
Wang, J., Neil, M., Fenton, N. (2020). A Bayesian Network Approach for Cybersecurity Risk Assessment Implementing and Extending the Fair Model. Computers \& Security, 89.

Wang, A., $\emptyset$ fsdahl, T., Mørch-Storstein, O. (no date). Collaborative Learning Through Games: Characteristics, Model, and Taxonomy. Online: $<$ www.idi.ntnu.no/grupper/su/publ/alfw/LectureGameTaxonomyPaper.pdf $>$. Access date: 12 November 2019.

Michat Mijal, PhD - University of Warsaw, Faculty of Management. Ph.D. in Economics, Assistant Professor in Chair for Organisational Theory and Methods. Works on social aspects of management and the use of games and simulations in management

Martyna Cieśla, M.A. - University of Warsaw, Faculty of Management. Graduate of the Pedagogical Faculty and the Institute of Specialist and Intercultural Communication at uw, research worker in Chair for Organisational Theory and Methods. One of the first in Poland to study the educational potential of escape rooms. Currently member of several international Horizon 2020 projects

Monika Gromadzka, PhD - University of Warsaw, Faculty of Education. PhD in Social Science, Assistant Professor at the Department for Adult Education and Andragogy. Her research interests are learning in middle adulthood and informal education

\section{Escape room jako narzędzie edukacji dorosłych}

Abstrakt: Stosowanie gier jako narzędzi nauczania jest coraz popularniejsze. Jednak użycie escape roomów stanowi nowość i większość autorów koncentruje się raczej na opisie samego narzędzia niż na analizie efektów jego zastosowania. Celem artykułu jest analiza doświadczeń osób biorących udział w edukacyjnym escape roomie oraz spojrzenie z perspektywy badacza zainteresowanego skutecznością narzędzia. Materiał badawczy pochodzi z wypetnionych przez uczestników kwestionariuszy oraz transkrypcji wywiadów ustrukturyzowanych. Dzięki stosunkowo dużej próbie ( $N=258)$ możliwe było stwierdzenie na podstawie danych ilościowych, że wiedza uczestników wzrosła.

Stowa kluczowe: escape room, edukacja dorosłych, serious games, wywiady ustrukturyzowane 